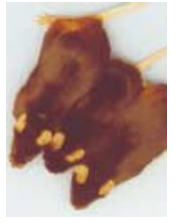

\title{
Fears for basic science as Bush backs use of investment criteria
}

\section{Colin Macilwain, Washington}

The White House has fuelled growing fears among scientific leaders that the recent era of expansion in US science funding is coming to a close. On 25 August, it announced plans to set new "investment criteria" next spring for all research programmes, including those in basic science.

Reports that the National Science Foundation (NSF) and the Office of Science at the Department of Energy (DOE) are planning to cut their budgets for 2003 have added to scientists' worries.

Eight months into the Bush administration, scientific leaders are also increasingly concerned about their lack of access to the White House. John Marburger, director of the Brookhaven National Laboratory in New York state, who was named as Bush's science adviser in June, has not come to Washington as a consultant, as the science community would have liked, in advance of his expected confirmation by the Senate next month.

No other senior research position in the administration has yet been filled, and the three most senior officials left from the Clinton administration - NSF director Rita Colwell, NASA administrator Dan Goldin, and Richard Klausner, director of the National Cancer Institute - are each tipped to leave their positions soon. So is energy secretary

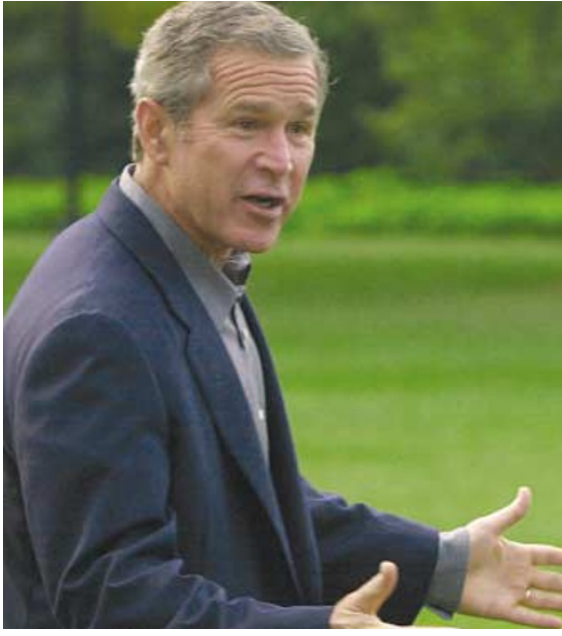

Spencer Abraham - sworn in this January - who may run for governor of Michigan.

Bush's plan, released by the White House Office of Management and Budget (OMB), says the criteria-based approach is being tested now on the DOE's applied research programmes in energy supply and conservation.

The OMB will next confer with the five main science agencies - the National Institutes of Health, the NSF, the DOE, NASA and the Department of Defense - before extending the approach to all basic research programmes. The chosen criteria will be

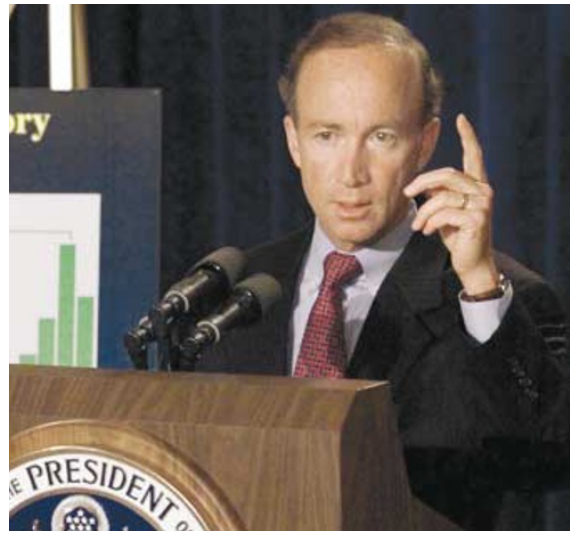

Mitch Daniels (above) and George Bush plan new performance measures for basic research.

published in the spring and will be used to develop budgets for the 2004 fiscal year.

Science lobbyists fear that the proposal will hurt basic science by demanding quick pay-offs. One senior lobbyist says of the officials driving the new policy, who include Mitch Daniels, the OMB's director: "They don't know what basic research is. They think that it should all be done by industry."

But White House officials argue that the $\mathrm{OMB}$ will listen to scientists' views before establishing the criteria for basic research. http://www.whitehouse.gov/omb/budget/fy2002

\section{Stanford gift scaled back over federal stem-cell policy}

\section{Rex Dalton, San Diego}

A technology entrepreneur has withdrawn $\$ 60$ million of a \$150-million gift for a biomedical research facility at Stanford University in California, in protest at US policy on stem-cell research.

James Clark - a former Stanford professor who made his fortune founding Silicon Graphics and Netscape — made his announcement in The New York Times on 31 August. He said he would hold the gift to $\$ 90$ million because of the Bush administration's decision to limit stem-cell research funding to a small number of cell lines already in existence (see Nature 412, 665; 2001).

Clark wrote that this plan was "beyond comprehension" and "driven by ignorance, conservative thinking and fear of the unknown".

Clark had pledged to build a new centre for biomedical engineering and science known as Bio-X - at Stanford. The centre was conceived to encourage collaboration between Stanford's schools for biology, engineering and computer science.

Construction of Bio-X began in the summer, and Stanford officials say they can still complete the building, but that Clark's action will delay funding for research projects at the centre. It is understood that Clark had originally planned to withdraw even more of his gift, halting construction entirely, but was dissuaded from doing so.

The withholding is the latest difficulty faced during the three years of planning for Bio-X. The building's size was scaled back to appease the surrounding community of Palo Alto. And in June, project director James Spudich said he would step aside this autumn. But after Clark's announcement, Spudich said he will remain as director for as long as is needed. 